\title{
Towson University
}

Department of Economics

\section{Working Paper Series}

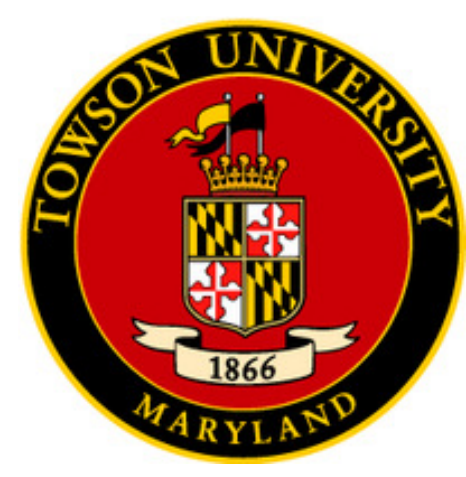

Working Paper No. 2010-14

\section{Fair Trade-Organic Coffee Cooperatives, Migration, and Secondary Schooling in Southern Mexico}

\author{
By Seth R. Gitter, Jeremy G. Weber, Bradford L. Barham, \\ Mercedez Callenes, \& Jessa M. Lewis
}

August, 2010

(C) 2010 by Authors. All rights reserved. Short sections of text, not to exceed two paragraphs, may be quoted without explicit permission provided that full credit, including (c) notice, is given to the source. 


\title{
Fair Trade-Organic Coffee Cooperatives, Migration, and Secondary Schooling in Southern Mexico ${ }^{1}$
}

\author{
Seth R. Gitter ${ }^{2 *}$, Jeremy G. Weber**, Bradford L. Barham**, Mercedez Callenes*** , \& Jessa M. \\ Lewis** \\ *Towson University \\ **University of Wisconsin-Madison \\ ***Grupo de Analisis para el Desarrollo (GRADE), Peru
}

\begin{abstract}
From 1995 to 2005 educational attainment of youth in rural Southern Mexico rose dramatically. Three distinct trends emerged in the region that could explain the rise in education. First, thousands of coffee-producing households joined cooperatives that have entered Fair Trade relationships and/or began adopting organic practices. Then, beginning in approximately 2000, US migration took off, while intra-Mexico migration steadily increased, providing remittance income and more lucrative alternatives in labor markets outside of coffee production. Third, Progresa/Oportunidades, a conditional cash transfer program aimed at promoting education, became available to families in the region in 1998 and 1999. Using survey data from 845 coffee farming households in Oaxaca and Chiapas, Mexico, this paper explores how participation in Fair Trade-organic cooperatives coffee price premiums, migration, and Progresa/Oportunidades shape education attainment for young adults (16-25). Results from a household fixed-effects model show that participating in a Fair Trade-organic cooperative contributed to a one-half year increase in schooling for girls over the study period. The impacts of US migration opportunities appear to have even stronger positive impacts on years of schooling for females, while for males increased migration opportunities tend to diminish the positive effects of being in a Fair Tradeorganic cooperative on educational attainment.
\end{abstract}

JEL Codes: N56, I20, F22

Key Words: Latin America, Mexico, Fair Trade, Organic, Migration, Education

\footnotetext{
${ }^{1}$ The primary data utilized in this paper are from the survey project, "Fair Trade-Organic Coffee, Rural Development, and Migration from Southern Mexico," led by Josefina Aranda, Jessa Lewis, Tad Mutersbaugh, and David Runsten, and funded by the Rockefeller Foundation. We would also like to thank Ayesha Enver, Chris Taber, and seminar participants at the Midwest Economics Association meetings and GRADE for their comments on previous drafts. All errors remain our responsibility.

${ }^{2}$ Seth Gitter is the corresponding author. Department of Economics Towson University Towson, MD 21252 phone-410.704.2191, fax-410.704.3424 e-mail-sgitter@towson.edu
} 


\section{Introduction}

Recent research on secondary school outcomes in Latin America has explored three major changes that could affect the education investments of poor households. The first, broadly speaking, concerns how changes in economic opportunities, ranging from coffee price movements to labor market trends to natural disasters, shape child labor versus schooling choices ([Levinson et al., 2001], [de Janvry et al., 2006], [Krueger, 2007], and [Gitter and Barham, 2007]). The second examines the impact of migration and remittances on education outcomes ([McKenzie and Rapoport, 2007a] and [Edwards and Ureta, 2003]), while the third focuses on the effects of conditional cash transfer programs, such as Mexico's famous Progresa, now known as Oportunidades ([Schultz, 2004] and [Rawlings and Rubio, 2005]). This article provides an integrated theoretical and empirical strategy for exploring the impacts of these types of changes on secondary school attainment in southern Mexico.

Southern Mexico provides an excellent location for studying how changes in earnings opportunities for poor agricultural households and rural youth could be reshaping schooling attainment in Mexico and Central America. First, the region holds potential for high agricultural returns associated with expanding markets for non-traditional export crops, including in some areas Fair Trade ${ }^{3}$ and/or organic certified products such as coffee. ${ }^{4}$ Second, there is the potential for higher individual and household incomes through migration to the United States or within countries and the region (Clark et al., 2004). Finally, conditional cash transfer programs, such as Progresa/Oportunidades in Mexico, RED de Proteccion Social in Nicaragua, and PRAF in

\footnotetext{
${ }^{3}$ This refers to coffee certified according to the norms of the Fair Trade Labelling Organizations International (FLO).

${ }^{4}$ Giovannuci et al. (2008) estimated that in 2005 alone U.S. imports of certified coffee from around the world almost doubled, from 60,000 to 110,000 metric tons.
} 
Honduras, require school attendance for rural youth in return for cash (Hoddinott and Weismann, 2008). These three changes have been underway for longer and are more substantial in their reach in Southern Mexico than in Central America. This article explores how these changes are affecting educational attainment for young adults (16-25 year olds) using a random stratified sample of 845 coffee farming households in Oaxaca and Chiapas, Mexico surveyed in 2005-06.

We open with a contextual discussion of the expansion of Fair Trade-organic coffee activity, migration trends, and Mexico's conditional cash transfer program for education. Next, we structure the empirical analysis with a formal model of labor/schooling decision for an adolescent in a coffee producing household. This model provides a set of testable hypotheses on how schooling attainment for young males and females could vary with household participation in Fair Trade-organic cooperatives, income transfers, and migration options. These hypotheses are then examined using a household fixed-effects econometric model that controls for the potential time invariant endogeneity of the household decision to join a cooperative. ${ }^{5}$ We further split the data by households with and without a US migrant to examine migration's effect on the relationship between participation in Fair Trade-organic cooperatives and schooling. The estimation results are also used in a decomposition analysis to identify the primary drivers of the dramatic change in educational attainment that has occurred among female youth in our sample.

Our core findings can be summarized as follows. First, we find that for females their household's participation in a cooperative with access to Fair Trade/organic markets contributes about one fourth of the two-year increase in average educational attainment that has occurred

${ }^{5}$ Household fixed effects control for wealth endowments that can affect migration. Massey et al. (1994) and McKenzie and Rapoport (2007b) show that middle class households with the resources to send migrants, and larger potential gains from migration, are most likely to migrate. 
from the 16 year old cohort to the 25 year old cohort. This effect is also positive for males but not as strong. Second, higher community migration rates to the United States (our proxy for migration and remittances) interacted with family structure contributes almost 1.3 years of additional schooling for females, or about three times the effect of participation in a cooperative. The effect is again weaker for males, as they are more likely to work or migrate to the United States at younger ages. Third, the effect of Oportunidades (estimated in Schultz, 2004) on female educational attainment is similar in magnitude to the higher return associated with the effect of household participation in a Fair Trade-organic cooperative. Together, these trends help to explain recent and large increases in female educational attainment among our sample households.

\section{Context: Coffee, Migration, and Cash Transfers}

Especially as children move into their teens, school enrollment choices for poor rural households involve stark tradeoffs between the potential returns to schooling versus the direct costs of schooling and the opportunity cost of forgone labor returns from their children (Basu, 1999). Households in many rural communities of Southern Mexico and Central America earn much of their income by growing coffee, which is intensive in labor; this makes it both a source of finance for education and an opportunity for generating family earnings from child labor ([Gitter and Barham, 2007], [Krueger,2007], [Gitter and Barham, 2009]).

Participation in Fair Trade-organic cooperatives is a relatively new phenomenon for the households in our sample. In 1995 only nine percent of households participated in a cooperative compared with 42 percent in $2005 .{ }^{6}$ Furthermore, almost all sampled cooperatives were certified to sell to the Fair Trade market by 2005 and most of their members held an organic certification. Both markets provide opportunities for higher prices. At the time of study, Fair

\footnotetext{
${ }^{6}$ Unless otherwise noted, descriptive statistics are weighted to account for oversampling.
} 
Trade rules stipulated a minimum price of $\$ 1.26$ per pound of coffee, or $\$ 0.05$ per pound above the world price, whichever was higher. Coffee that was also certified organic received an additional $\$ 0.15$ per pound (for a total minimum price of $\$ 1.41) .^{7}$ This payment goes to the producer cooperative, which subtracts expenses before paying members. In our sample, coffee farmers participating in cooperatives earned about $\$ 150$ per hectare more than non-

participating farmers, which translates into $\$ 440$ for the average sized cooperative farm, or 13 percent of the sample mean household income.

It is important to clarify the nature of participation in Fair Trade and organic markets. Households participate in both markets through grower cooperatives that oversee compliance with certification standards. However, the Fair Trade certification operates at a cooperative level in the sense that if the cooperative is certified then all members can sell (via the cooperative) to the Fair Trade market. Organic certifications also operate at the cooperative level (in the case of small-scale farmers), but in a different way. Each member seeking organic certification must comply with specified norms for a set period before they can sell to the organic market through their cooperative. Therefore, unlike Fair Trade, individual members of the cooperative must receive organic certification in order to sell to the organic market. In our sample, all cooperatives had Fair Trade certification and 99\% of the members of Fair Trade cooperatives were at least transitioning to organic certification.

By raising returns to coffee production and insulating producers from price shocks (such as the severe price decline in 2000-2003), Fair Trade and organic coffee arrangements create cross cutting effects for education decisions in rural households. On the positive side are the

\footnotetext{
${ }^{7} \$ 1.41$ per pound refers to the Fair Trade minimum price during the study period for washed Arabic coffee with an organic certification.
} 
income effect ${ }^{8}$ from price premiums and the risk reduction effect of more stable prices in certified coffee markets, both of which should aid rural households' investments in education.

On the negative side is the potential increased opportunity cost of the child's time in school, especially for poorer households that might not be able to finance hired labor (Gitter and Barham, 2009). Krueger (2007) finds that education decreased during times of higher coffee prices in Brazil, which suggests that the substitution effect can dominate the income effect. Furthermore, income and substitution effects may affect males differently than females. Males typically provide more year-round labor on coffee farms. They are also more likely than girls to work in rural labor markets, though girls are more likely to perform non-wage labor in the household (Levinson et al., 2001). Overall, we might expect substitution effects to most affect adolescent males in coffee growing households.

Traditionally, labor opportunities for Southern Mexican households depended primarily on local or perhaps regional activities. Since the late 1990s, however, migration to the United States has exploded, while intra-Mexico migration has also grown markedly. In the sample, 25 percent of households had a member living in the United States in 2005 as compared to three percent in 1998. Likewise, migration within Mexico expanded from just over 20 percent of households in 1998 with a member living elsewhere in the country to close to 40 percent in 2005. These trends reflect both lifecycle effects of families and the expansion in migration that occurred throughout the region during this era. Using data from the US Department of Homeland Security, the Migration Policy Institute estimates, for example, that the number of US inhabitants born in Mexico increased from 6.7 to 10.9 million between 1995 and 2006, and that similar percentage increases occurred for people born in Central America.

\footnotetext{
${ }^{8}$ Income does not affect schooling in the original Becker model (1964). If, however, borrowing constraints exist or if education has value as consumption, income will affect schooling decisions.
} 
As with participation in a Fair Trade-organic coffee cooperatives, migration opportunities, especially to the United States, could affect household decisions to invest in education. Migration of parents, relatives, or grown children frequently provides remittance flows to finance education of youth; for sample households with a US migrant, remittances represent almost two-thirds of household income. Migration can also change returns to schooling by opening new labor markets that may or may not reward marginal increases in child education ([McKenzie and Rapoport, 2007a], [Chiquiar and Hanson, 2005] and [Borjas, 1987]). As Borjas and others document, the pull of US migration may decrease the incentive to complete high school, because of low returns to Mexican schooling earned in unskilled jobs in the United States. On the other hand, domestic migration opportunities could increase returns to education as jobs within Mexico value higher levels of education. Davis et al. (2002) find that for migration within Mexico, education increases the likelihood of migrating for non-agricultural work while the opposite is true for agricultural work.

Migration could affect males and females differently, particularly if labor market opportunities in Mexico or the United States vary by gender. Young males migrate internationally more than young females. In the sample about 25 percent of males between the ages of 20 and 30 had migrated to the United States, which is about three times the prevalence of females of the same age. Also, consistent with more local labor market opportunities for males, Amuedo-Durantes and Pozo (2006) found that remittances were more likely to decrease female labor supply compared to males. Both of these effects could translate into higher educational attainment among adolescent girls.

Oportunidades (formerly called Progresa) has been in place in our study region in Southern Mexico since 1998-99. Since 1995, the Mexican government has been at the international forefront of promoting educational attainment for the poor, (Fiszbein and Schady, 
2009), with almost one in five Mexican households participating in Oportunidades (Rawlings and Rubio, 2005). Evaluations have verified its positive effects on schooling of younger children ([Schultz, 2004], [De Janvry et al., 2006]), and more recently its coverage was extended to include college. Oportunidades was present in every sampled community, and over 80 percent of households participated, with the average annual payment approaching $\$ 500$ per household, an amount similar to the average net coffee revenue.

The incidence, duration, and support level of Oportunidades suggest that it could transform investments in education. Yet, the simultaneous expansion of other income and labor opportunities offers a complex set of trends worth exploring. This article helps unpack how increased agricultural returns, migration opportunities, and Oportunidades have shaped educational attainment of youth from some of the poorest regions of Mexico.

\section{A Simple Model of Coffee Growing and Schooling}

To guide our empirical analysis, we present a theoretical model that has testable implications. Consider a household deciding how to allocate an adolescent's time between schooling (s) and coffee production (1-s). Coffee production is assumed to be a decreasing returns to scale technology $f($.$) that for simplicity requires only labor. The family can produce$ coffee with its own labor or hired labor (I); the two are assumed to be perfect substitutes. For simplicity, we assume that adult household labor is fixed. Therefore, the amount of labor used in coffee production is $(1-\mathrm{s}+\mathrm{l})$ and the fixed adult labor that is implicit in the production function. The adolescent only works on-farm. If the household needs more labor, it can hire at wage w.

The wage is an increasing function of the price of coffee $(p)$ and the community migration rate $\left(M_{c}\right)$. Intuitively, more migration means less labor supply in the sending community. It can also mean greater labor demand as migrants remit money to their home 
community, stimulating demand for other labor services. Indeed, in our sample US migration rates and community average remittances are positively correlated with community average wages. Note that the wage is not a function of the coffee price premium, which assumes no general equilibrium effects from premiums or the adoption of potentially labor intensive organic standards.

The family receives $p$ for coffee if it is uncertified while it receives an additional per unit premium $(\pi)$ if it is certified as Fair Trade-organic. A natural question is why some farmers are not certified. Organic certification is costly, and includes a substantial time commitment of cooperative meetings. Additionally, costs vary across households. Some households live far from the nearest cooperative and distance increases the cost of attending workshops important for fulfilling certification standards. More importantly, some aspects of certification costs like documentation of farming practices are unrelated to farm size. As a result, larger farms face lower average certification costs; indeed organic farms in the sample are on average 50 percent larger than non-organic farms. This finding is consistent with a class of technology adoption models that find higher fixed costs favor adoption by larger farms (e,g., Feder, 1980).

To incorporate the decision to certify into the model we suppose that the household faces a certification cost of $\theta$. The farm will be certified if the increased revenue from the premium price exceeds certification cost: $(p+\pi) f\left(L^{*}\right)-p f\left(L^{\prime}\right)+w\left(L^{\prime}-L^{*}\right)>\theta,{ }^{9}$ where $L^{*}$ and $L^{\prime}$ are the profit maximizing labor levels with and without the premium.

Remittances or government transfer payments enter into our framework by giving the household an exogenous income transfer y. Similar to Krueger (2007) the family derives utility from consumption $\mathrm{U}(\mathrm{c})$ and schooling $\mathrm{V}(\mathrm{s})$ where both $\mathrm{U}$ and $\mathrm{V}$ are strictly concave functions.

\footnotetext{
${ }^{9}$ Additional benefits may include technical assistance and help with purchasing coffee production capital. To make the model tractable we do not include these benefits.
} 
Assuming a separable utility function, the farmer maximizes $U(c)+V(s)^{10}$ subject to the constraint specified in equations 1.1 or 1.2 .

$$
\begin{array}{ll}
c=y+(p+\pi) f(1-s+l)-w\left(p, M_{c}\right) l-\theta & \text { if }(p+\pi) f\left(L^{*}\right)-p f\left(L^{\prime}\right)-w\left(L^{\prime}-L^{*}\right)>\theta \\
c=y+p f(1-s+l)-w\left(p, M_{c}\right) l & \text { otherwise }
\end{array}
$$

Substituting the expression for $\mathrm{c}$ into $\mathrm{U}(\mathrm{c})$ yields an unconstrained maximization problem where the farmer chooses labor hired I and schooling s. We consider the case of the certified farmer:

$$
\operatorname{Max}_{\mathrm{s}, 1} U\left(y+(p+\pi) f(1-s+l)-w\left(p, M_{c}\right) l-\theta\right)+V(s)
$$

Assuming an interior solution, the first order conditions are

$$
s^{*}: U^{\prime}(p+\pi) f_{l}=V^{\prime} \quad \text { (3.1) } \quad l^{*}:(p+\pi) f_{l}=w\left(p, M_{c}\right)
$$

where $U^{\prime}$ and $V^{\prime}$ are marginal utilities and $f_{l}$ is the marginal productivity of agricultural labor. The FOCs are intuitive. Under optimality, the marginal utility of consumption multiplied by the marginal value product of allocating one more unit of adolescent labor to coffee farming must equal the marginal benefit from schooling. Because the household can hire in labor, the marginal value product of agricultural labor must equal the wage (equation 3.2). Combining the two conditions yields:

$$
\frac{V^{\prime}}{U^{\prime}}=w\left(p, M_{c}\right)(4)
$$

From the FOCs summarized in (4) we can derive relevant comparative statics. The premium $\pi$ and the cash transfer $y$, which could be from conditional cash transfers or remittances, ${ }^{11}$

\footnotetext{
${ }^{11}$ Conditional cash transfers may also include minimum schooling time, however we do not include this to make the model tractable. Their inclusion would not change the basic results.
} 
increase schooling. By increasing income, they lower the marginal benefit of allocating the adolescent's labor to coffee farming.

$$
\frac{\partial s^{*}}{\partial \pi}>0 \quad \text { (5.1) } \quad \frac{\partial s^{*}}{\partial y}=>0
$$

Because a higher wage (either from a higher $p$ or a higher $M_{c}$ ) decrease profits from coffee farming and by extension income, it has the opposite effect on schooling.

$$
\frac{\partial s^{*}}{\partial w}<0
$$

The premium induces only an income effect because labor can be freely bought in our model. Large swings in world coffee prices undoubtedly affect employment and wages in coffee growing regions ([Varangis et al., 2004] and [Krueger, 2007]). Fair Trade-organic premiums paid to a small proportion of growers for some of their coffee, however, are unlikely to significantly affect wages, even though adoption of more labor-intensive organic production methods increases labor demand to a moderate degree. For example, a simple regression of labor use on regional dummies and a dummy for whether a farmer has at least transitioned to organic suggests that organic farmers use 10 more labor days per hectare per year ${ }^{12}$, which is about a 15 percent increase over conventional farm labor use. Overall, participation in Fair Trade-organic coffee production most likely has a small effect on labor demand and wages. Hence, we find it reasonable to make wages a function of only the world coffee price and not the premium.

If households were limited in how much labor they could hire, either because of shallow rural labor markets or liquidity constraints, then the opportunity cost of schooling would be a household specific shadow wage tied to agricultural returns. In this case, the premium would

\footnotetext{
${ }^{12}$ It is very possible that more able farmers participate in cooperatives and by extension use organic practices, especially since cooperative farmers have much higher yields than non-cooperative farmers. In the case of positive selection, the estimate of 10 days represents an upper bound on the effect of organic practices on labor intensity.
} 
induce a substitution effect that would work against the income effected highlighted earlier. Krueger (2007) and Gitter and Barham (2009) show that in some instances the substitution effect may dominate the income effect. Similarly, when labor markets are tight, general equilibrium effects may increase agricultural wages that could create a similar substitution effect if adolescents work off-farm. It is important to note that under imperfect labor markets price premiums may affect male and female children differently since males participate more in agriculture.

A higher wage decreases the effect of the premium on schooling. The same holds for community migration rates since migration increases the wage in the sending community.

$$
\frac{\partial^{2} s^{*}}{\partial \pi \partial w}<0 \quad \text { (7.1) } \quad \frac{\partial^{2} s^{*}}{\partial \pi \partial M_{c}}<0 \quad \text { (7.2) }
$$

Intuitively, the premium increases the marginal value product of labor, increasing labor demand, output, and income. With a higher $w$, the premium will have a smaller effect on income because expanding production is more costly. In short, a higher w decreases the income effect of the premium. A similar result is that the cash transfer $y$ also attenuates the income effect of the premium:

$$
\frac{\partial^{2} s^{*}}{\partial \pi \partial y}<0
$$

At higher income levels, the increase in income and consumption caused by the premium has a smaller effect on the marginal utility of consumption since $U$ is strictly concave. The household, therefore, needs to withdraw a smaller amount of its own labor from coffee farming (and by extension increases schooling less) to satisfy equation 4 after the introduction of the premium.

We can incorporate gender into the model via labor productivity and the benefit derived from education $V(s)$. Specifying a different $V(s)$ for boys and girls is equivalent to assuming 
different benefits of education for boys and girls. Lower returns from female labor could be captured by scaling female agricultural labor $0<\eta<1$ such that a unit of female labor produces less than a unit of male labor. If we assume that $\mathrm{V}(\mathrm{s})$ is the same for boys and girls, and that boys have higher agricultural labor productivity, then males should have lower schooling than females. ${ }^{13}$ Furthermore, continuing to assume that $V(s)$ is the same for boys and girls, the certification premium will increase the schooling of girls more than for boys. The premium increase household income and consumption. To satisfy the condition in equation 4 , the household replaces its own labor with hired labor (implicitly increasing schooling in the process). Because male labor is more productive than female labor, the household needs to withdraw less male labor to once again satisfy equation 4.

Our simple model of child labor allocation assumes well functioning labor markets and no general equilibrium effects of coffee price premiums on wages. We highlight four predictions of the model that guide our empirics.

1. Participation in Fair Trade-organic cooperatives should increase schooling, though more so for girls than boys.

2. Access to income transfers through remittances or government programs should increase schooling.

3. Higher community migration rates should decrease schooling by increasing wages and decreasing income from coffee growing. Though outside of the model, higher community migration rates also improve migration networks which lower the cost of migrating. Both effects could decrease schooling especially for boys if they are more likely to migrate as adolescents. One could also imagine that adolescents occasionally work off-farm, in which case an increase in w increases the opportunity cost of schooling.

\footnotetext{
${ }^{13}$ This result can be seen by incorporating the female labor scalar into the maximization problem, in which case equation (4) becomes $\frac{V^{\prime}}{U^{\prime}}=\eta w\left(p, M_{c}\right)$. Since $\eta$ is less than one, the ratio of marginal utilities will be lower, meaning that $\mathrm{V}^{\prime}$ must be lower and $\mathrm{s}$ higher.
} 
4. Higher community migration (and hence higher wages) should attenuate the positive effect of Fair Trade-organic cooperative participation on schooling.

The model does not explicitly explore liquidity constraints. However, coffee cooperatives may help alleviate some of the negative effects of credit constraints on educational attainment mentioned in the literature ([Gitter and Barham, 2007], [Beegle et al., 2003] and [Brown and Park, 2002]). Some cooperatives in the study have associated organizations that extended credit to members. Credit could help households smooth consumption and meet beginning of school year expenses such as books and uniforms. Additionally, access to more stable Fair Trade-organic coffee prices could increase schooling since households sometimes remove children ex-ante of negative shocks to insure consumption.

\section{Data Description and Descriptive Statistics}

This study is based on a survey conducted in southern Mexico between August 2005 and June 2006. The survey included 845 coffee farming households in 9 regions and two states; 640 households are from the state of Oaxaca and 205 from the state of Chiapas. While communities were chosen on the basis of having a Fair Trade-organic cooperative and to be regionally representative of the coffee growing areas, households were selected as part of a random stratified sample. Coffee producers in each region were enumerated and divided into two basic groups: those that are organized and participate in Fair Trade-organic coffee production and those that do not. Each group was further stratified by prior information on migration history, and a random sample was drawn from the strata. Each coffee household was weighted appropriately in the descriptive analysis according to the selection probability of their particular stratum. ${ }^{14}$ For a more detailed description of the data, sample frame, and survey instrument see Lewis and Runsten (2009). The survey included socio-demographic questions on household

\footnotetext{
${ }^{14}$ We do not reweight the econometric estimates, because they are used for inference rather than developing representative descriptive statistics of the population.
} 
members and their educational status as well as modules detailing individual migration experiences and a full range of income sources. Additionally demographic information was provided on former household members currently living abroad or in other parts of Mexico.

\section{Explosion in Educational Attainment}

We describe the recent growth in educational attainment and then return to the three major trends that may have shaped this expansion: the growth in Fair Trade-organic coffee cooperatives; migration to the United States and Mexico; and the introduction of Oportunidades. The descriptive discussion documents the timing and magnitude of these trends. The econometric analysis in the next section explores the relationship between them and educational attainment in a more systematic fashion.

Educational attainment has risen tremendously for young adults in our sample. Hanushek (1986) finds that for the United States the median years of school completed for 25 to 29 year olds increased by .9 from 1950 to 1980 . In contrast, 16 year old females in this sample had 1.9 years more schooling than 25 year old females. Table 1 shows that the percentage of men that completed at least $9^{\text {th }}$ grade (the final year of middle school in Mexico) has risen from 10 percent for the age cohort 41-50, to almost 70 percent for the youngest cohort of children 17-19. Female educational attainment experienced a similar take-off, with $9^{\text {th }}$ grade completion rising from five percent for the $41-50$ cohort to 77 percent for the youngest cohort. Most of the growth in attainment occurred in the past decade, with the percentage completing middle school growing from 25 percent of the 26-30 age cohort to 73 percent for the current 17-19 age cohort. Also noteworthy is that in the youngest cohort (17-19) female educational attainment recently surpassed male attainment for the first time. This historic switch could be a result of both Oportunidades, which provides higher payments for girls, and better off-farm earning and migration opportunities for males. 
Table 1: Completed $9^{\text {th }}$ Grade by Age Cohort Age

\begin{tabular}{lcccccc} 
& $17-19$ & $20-22$ & $23-25$ & $26-30$ & $31-40$ & $41-50$ \\
\hline Male & $69 \%$ & $60 \%$ & $54 \%$ & $29 \%$ & $21 \%$ & $10 \%$ \\
Female & $77 \%$ & $55 \%$ & $44 \%$ & $21 \%$ & $10 \%$ & $5 \%$ \\
\hline Total & $73 \%$ & $58 \%$ & $48 \%$ & $25 \%$ & $15 \%$ & $8 \%$ \\
\hline
\end{tabular}

The prevailing pattern in Mexico is that once children start in a level of school they typically finish it (Metha and Villarreal, 2008). This trend is evident in our data, and justifies our focus on educational attainment of children of secondary school age. Note in Table 2 that in Mexico primary school consists of the first 6 years of school, middle school the 7-9th year, and high school the $10-12^{\text {th }}$ year. Table 2 shows the cumulative percentage of children who have completed at least the number of schooling years listed. Most children ( 80 percent or more) completed at least primary school, with 97 percent of the 16 year old cohort having completed the requisite 6 years. Roughly 20 percent of the $16-18$ year olds in the sample drop out after primary school and during middle school. Of those who continue to middle school, about 90 percent complete it. Most youth drop out between middle school and high school, with around 30-40 percent ending their schooling after 9 years. Because the key transition points are between the $6^{\text {th }}$ and $7^{\text {th }}$ year (when a child is 12 years old) and between the $9^{\text {th }}$ and $10^{\text {th }}$ year (when a child is 15 years old), we focus the econometrics on educational attainment outcomes of a child at age 15. Similar results emerge in a parallel analysis of 12 year olds in the sample. Additionally, we find similar results for the main variables of interest when we restrict our sample to $19-25$ year olds to control for the fact that many $16-18$ year olds are still in school. 
Table 2: Distribution of Years of School Completed for the Sample

\begin{tabular}{lccccccccc} 
Age & 16 & 17 & 18 & 19 & 20 & 21 & 22 & 23 & 24 \\
\hline Less than 6 Years & $100 \%$ & $100 \%$ & $100 \%$ & $100 \%$ & $100 \%$ & $100 \%$ & $100 \%$ & $100 \%$ & $100 \%$ \\
6 Years & $97 \%$ & $88 \%$ & $91 \%$ & $88 \%$ & $85 \%$ & $84 \%$ & $82 \%$ & $84 \%$ & $75 \%$ \\
7-8 Years (Some Middle School) & $88 \%$ & $76 \%$ & $76 \%$ & $67 \%$ & $62 \%$ & $53 \%$ & $49 \%$ & $50 \%$ & $49 \%$ \\
9 Years & $75 \%$ & $69 \%$ & $69 \%$ & $61 \%$ & $60 \%$ & $49 \%$ & $47 \%$ & $44 \%$ & $46 \%$ \\
$10-11$ Years & $27 \%$ & $31 \%$ & $28 \%$ & $26 \%$ & $23 \%$ & $17 \%$ & $13 \%$ & $16 \%$ & $7 \%$ \\
12 Years+ & $4 \%$ & $12 \%$ & $17 \%$ & $22 \%$ & $19 \%$ & $16 \%$ & $11 \%$ & $14 \%$ & $6 \%$ \\
\hline
\end{tabular}

The Household Economic Context: Income Sources, Labor Markets, and Coffee

Mean household income is about 33,000 pesos (10 pesos: $1 \$$ ), and the decomposition shows that remittances, subsidies, coffee earnings, and non-agricultural activities are, in decreasing order, the leading sources of income for our sample of coffee producing households. Almost all households (96 percent) have subsidy income while most ( 85 percent) have positive net income from coffee. The mean income from different sources in Table 3 is unconditional.

Table 3: Sample Income Composition (In Pesos)

$\begin{array}{llc}\text { Income Sources } & \text { Mean } & \begin{array}{c}\text { HHs with Income } \\ \text { From Source }\end{array} \\ \text { Coffee (net revenue) } & 6120 & 85 \% \\ \text { Remittances } & 11503 & 35 \% \\ \text { Non-Coffee Agriculture } & 179 & 13 \% \\ \text { Subsidies (e.g. Oportunidades) } & 6488 & 96 \% \\ \text { Non-Agricultural Activities } & 5409 & 40 \% \\ \text { Off-Farm Agricultural Wages } & 2872 & 28 \% \\ \text { Sample } & 32570 & \end{array}$


Most households ( 80 percent) buy or sell labor or do both. The median number of days spent per household working off-farm in agriculture is 46, which is associated with a median income of 2,400 pesos ( $\$ 5$ per day). A little more than half of all households (54 percent) hire labor for coffee farming.

Forty-two percent of sample households participated in a coffee cooperative. Of these organized households, $99 \%$ were certified organic or in transition to receiving certification; certification generally takes three years during which farmers are classified as in transition. Because small farmers receive organic certification through a cooperative, all households with organic certification were also organized. In addition, 89 percent of organized households participated in cooperatives with Fair Trade certification.

Prices paid to growers and total net revenue per hectare, defined as revenue minus cash costs, increase from the non-organized group to the transition group to organic farmers. On average, non-organized households receive 6.71 pesos per $\mathrm{lb}$ for their coffee. Cooperative members in transition to organic receive about eight percent more (+0.55 pesos), while organic certified households receive almost 25 percent more than non-organized producers and 14 percent more than farmers in transition. Differences in prices and net revenue, however, may reflect differences between producers other than organic status or productivity improvements associated with organic practices, such as pre-existing differences in quality of production, land, or producer skill. The median numbers in Table 4, nonetheless, display the potential income effects associated with organic premiums assumed in the model.

Table 4: Median Prices and Net Revenue by Group

\begin{tabular}{ccc}
\hline Group & $\begin{array}{c}\text { Price Received } \\
\text { (Pesos/lb) }\end{array}$ & $\begin{array}{c}\text { Net Revenue per Hectare } \\
\text { (Pesos) }\end{array}$ \\
\hline Non-Organized & 6.71 & 1200
\end{tabular}




\begin{tabular}{lll} 
Transition & 7.26 & 2146 \\
Organic Certified & 8.47 & 2541 \\
\hline
\end{tabular}

The assumption that community emigration increases community wages is intuitive since the exodus of labor lowers labor supply. Furthermore, remittances that migrants send to their home communities could stimulate labor demand as well as further lower labor supply as households choose more leisure. The theoretical conjecture holds in our sample of 14 communities; the mean wage paid for day laborers on coffee farms in a community rises with the community's US migration rate.

\section{Rapid Growth in Migration}

As mentioned above, migration within Mexico and to the United States has taken off in recent years (Table 5). The proportion of sample households with a US migrant increased from two percent to 24 percent in the 10 year period, while the number of households with a Mexican migrant increased from 17 to 39 percent in the same period. Individual migration information from households allows us to estimate community level migration rates, which we combine with household characteristics to instrument for migration opportunities. Using community migration rates allows us to control for the effect of migration on schooling without explicitly modeling migration choices.

Migration rates and organic certification rates have both increased over the last decade; however, we do not find evidence that the two are related. In 2005 , the difference in the percentage of households with a US migrant was less than 1 percentage point between households with and without organic certification. Additionally a Probit regression, where the dependent variable is an indicator for having a US migrant in 2005 , does not show a statistically significant relationship between organic certification or length of certification and having a 
migrant. ${ }^{15}$ Similar results are found for the relationship of Intra-Mexico migration to organic certification.

Oportunidades

The final trend that we highlight is the introduction in 1998-1999 of Oportunidades. It was introduced in eight of the nine regions in 1998, and the final region received Oportunidades in 1999. The lack of variation in the timing of implementation prevents us from estimating direct impacts of Oportunidades. We do, however, compare estimates of year effects with estimates produced elsewhere to gauge Oportunidades' impacts

Table 5: Trends That May Affect Education Percent of Households with...

\begin{tabular}{ccccc}
\cline { 2 - 4 } Year & $\begin{array}{c}\text { Organic } \\
\text { Certification }\end{array}$ & a US Migrant & $\begin{array}{c}\text { a Mexican } \\
\text { Migrant }\end{array}$ & $\begin{array}{c}\text { \# Regions received } \\
\text { Oportunidades }\end{array}$ \\
\hline 1995 & $5 \%$ & $1 \%$ & $17 \%$ & 0 \\
1996 & $7 \%$ & $2 \%$ & $17 \%$ & 0 \\
1997 & $7 \%$ & $3 \%$ & $18 \%$ & 0 \\
1998 & $11 \%$ & $3 \%$ & $21 \%$ & 8 \\
1999 & $17 \%$ & $3 \%$ & $23 \%$ & 9 \\
2000 & $24 \%$ & $6 \%$ & $27 \%$ & 9 \\
2001 & $28 \%$ & $8 \%$ & $28 \%$ & 9 \\
2002 & $33 \%$ & $12 \%$ & $30 \%$ & 9 \\
2003 & $41 \%$ & $17 \%$ & $34 \%$ & 9 \\
2004 & $45 \%$ & $19 \%$ & $36 \%$ & 9 \\
2005 & $48 \%$ & $24 \%$ & $39 \%$ & 9 \\
\hline
\end{tabular}

\section{Econometric Model of Educational Attainment}

Our econometric analysis examines variation in educational attainment measured by years of schooling completed. Table 6 defines the main variables used. All variables were constructed based on a single observation with some variables being constructed based on recall data. For example, the Organized variable is constructed from a question asking when the

${ }^{15}$ Additional control variables such as household head's age and education as well as demographic variables were included. 
household joined the cooperative that it currently participates in. The migration variables are also constructed from the migration history of current household members and those that have since moved.

Table 6: Descriptive Statistics

\begin{tabular}{|c|c|c|c|}
\hline Variable & Mean & SD & Definition \\
\hline Schooling & 8.16 & 3.13 & Years of school completed at the time of the survey. \\
\hline Organized & 0.44 & 0.5 & $\begin{array}{l}\text { Indicates if the household participated in a cooperative when the } \\
\text { child was } 15 \text { (=1 if organized). }\end{array}$ \\
\hline Mig Mex & 0.28 & 0.13 & $\begin{array}{l}\text { The community's within-Mexico migration rate when the child was } \\
15 .\end{array}$ \\
\hline Mig US & 0.1 & 0.12 & The community's US migration rate when the person was 15 . \\
\hline Older Sibs & 2.49 & 2.19 & The number of older siblings. \\
\hline $\begin{array}{l}\text { Younger } \\
\text { Sibs }\end{array}$ & 2.61 & 1.83 & The number of younger siblings. \\
\hline Age & 20.31 & 2.85 & $\begin{array}{l}\text { Indicates that the person belongs to the cohort of age } \mathrm{j} \text { were } \mathrm{j} \text { ranges } \\
\text { from } 16 \text { to } 25\end{array}$ \\
\hline Female & 0.49 & 0.5 & Indicates the child's gender (=1 if female) \\
\hline
\end{tabular}

The dependent variable of interest is the number of years of school completed at the time of the survey. The sample includes all past and present household members who were between the ages of $16-25$ at the time of the survey. This eliminates the potential selection bias of not including almost $40 \%$ of the age cohort who do not currently live in the community, with $14 \%$ in the United States and $25 \%$ living in another region in Mexico at the time of the survey. In Table 2 we show that most children drop out after $9^{\text {th }}$ grade when children are typically 15 years old. The age range was chosen as those who were 25 at the time of the 2005 sample were 15 before the major trends of certification, migration, and Progresa/Oportunidades. 
The theoretical model and the literature guide the specification of our empirical model. Organized indicates if a household received a price premium, $\pi$, from participation in a Fair Trade/organic cooperative when the child was $15 .{ }^{16}$ While only the premium is formally modeled, Organized captures additional benefits from cooperative participation like access to extension services and possibly credit. The community migration rate, Mig US or Mig Mex ( $\mathrm{M}_{c}$ in the model) captures the general equilibrium effect of migration on wages and by extension schooling. To allow the premium $\pi$ to affect schooling less in high migration/high wage communities, we interact Organized with community migration rates.

The full effect of migration depends on whether a child actually benefits from remittances. We use household structure to proxy for the likelihood of a child being in a migrant or remittance household. Children with older siblings in high migration villages are more likely to benefit from remittances. Conversely, the need for remittances may be greater if the child has many younger siblings. A higher expectation of US migration should decrease incentives to stay in school.

The age fixed-effect term $\gamma$ corrects for temporal factors affecting all children of the same cohort such as economic shocks (particularly to world coffee prices) or the introduction of Oportunidades. We include a household fixed effect $\alpha$ to control for time invariant differences between organized and non-organized households. Identification of the effect of participation in Fair Trade/organic cooperatives comes from variation across time in a household's organizational status; from 1995 to 2005 the percent of organized households in our sample increased from less than $10 \%$ to almost $50 \%$. The household fixed-effect specification compares educational attainment of a child which was 15 prior to the household becoming organized with

${ }^{16}$ The Organized group includes both certified organic households and households in transition to certification. In a preliminary analysis we broke the Organized group into organic transition and certified organic households and found no evidence that the groups have different schooling patterns. 
that of a child that turned 15 after the household became organized. There are 98 households that fall into the category of having children who were 15 before and after the household became organized.

Model 1 is our regression of educational attainment that we estimate separately for males and females. The dependent variable is the schooling of child " $\mathrm{i}$ " in household " $\mathrm{h}$ ", living in community "c". These distinctions are important as we control for individual, household and community characteristics within the estimation. To clarify notation, $\alpha_{h(i)}$ is the household fixed effect for person $i$.

Model 1: Separate Regressions for Males and Females

Schooling $_{i}=\theta_{o}+\theta_{1}$ Organized $_{h(i)}+\theta_{2} \operatorname{Mig~US}_{c(i)}+\theta_{3} \operatorname{Mig~Mex~}_{c(i)}+\theta_{4}$ Older Sibs $_{i}+\theta_{5}$ Younger Sibs $_{i}+$ $\theta_{6}\left(\operatorname{Mig~US}_{c(i)} *\right.$ Older Sibs $\left.i\right)+\theta_{7}\left(\operatorname{Mig~US}_{c(i)} *\right.$ Younger Sibs $\left.i\right)+\theta_{8}\left(\operatorname{Mig~Mex}_{c(i)} * \operatorname{Older}_{\mathrm{Sibs} i}\right)+$ $\theta_{9}\left(\operatorname{Mig~Mex}_{c(i)} * \operatorname{Younger~Sibs}_{i}\right)+\theta_{10}\left(\operatorname{Organized}_{h(i)} * \operatorname{Mig}_{\mathrm{US}} \mathrm{S}_{c(i)}\right)+\alpha_{h(i)}+\gamma_{j(i)}+\mathcal{E}_{i}$

The second econometric model pools males and females. The pooled model includes all variables in the separate model (represented by the $k$ by 1 vector $x_{i}$ below) and several gender related variables. The variable Female captures gender differences like wage earning opportunities and returns to schooling. In addition we include three gender interaction terms: Organized*Female, Migration US*Female, and Organized*Migration US*Female. The interaction terms make sense if females participate in different labor markets than males or have different productivity in agriculture. If females earn less working, income from a premium should favor keeping girls in school more than boys. Likewise, migration should affect wages in male dominated activities the most since males migrate more than females. 
Model 2: Pooling Males and Females

Schooling $_{i}=\beta_{o}+\beta_{1} x_{i}+\beta_{2}$ Female $_{i}+\beta_{3}\left(\right.$ Organized $_{h(i)} *$ Female $\left._{i}\right)+\beta_{4}\left(\right.$ Migration US $_{c(i)} *$ Female $\left._{i}\right)+$ $\beta_{5}\left(\operatorname{Organized}_{h(i)} * \operatorname{Migration}_{\mathrm{US}_{c(i)}} * \mathrm{Female}_{i}\right)+\alpha_{h(i)}+\gamma_{j(i)}+\mathcal{E}_{i}$

The third and final model separates the sample by households with and without a

migrant at the time of the survey. The model drops the migration variables from model 1 . This

exogenous switching specification tests whether the potential endogeneity of community e migration rates affects the estimates for other key explanatory variables. It also allows us to see if the effect of participating in a FT-organic cooperative on schooling is different for migrant and non-migrant households. Thus, we estimate the following model (Model 3) separately for migrant and non-migrant households

Model 3: Migrant and Non-Migrant Regimes

Schooling $_{i}=\delta_{0}+\delta_{1}$ Female $_{i}+\delta_{2}$ Older Sibs $_{i}+\delta_{3}$ Younger Sibs $i_{i} \delta_{4}\left(\right.$ Organized $_{h(i)}{ }^{*}$ Female $\left._{i}\right)$ $+\alpha_{h(i)}+\gamma_{j(i)}+\varepsilon_{i}$

We estimate all models using ordinary least squares, assuming that the conditional mean of the error $\varepsilon_{\mathrm{i}}$ is zero. We report robust standard errors clustered at the household level

\section{Results}

The econometric estimates are shown in Table 7 and 8, and a decomposition of educational attainment increases is presented in Table 9. The first two sets of results in Table 7 present the separate regressions for males and females. The coefficient estimates in all of the regressions are of reasonable magnitude. Potential concerns about the robustness of the "organized" measure are considered in a falsification test that is presented in Appendix A. The significant coefficient estimates we obtain on the "organized" measures are unique to the 
temporally accurate specification, and are not obtained in the falsification test estimation where the timing of becoming organized is altered.

Overall, the results show that participation in Fair Trade-organic cooperatives and greater US migration opportunities are positively associated with female schooling. We also find age cohort effects consistent with positive impacts from Oportunidades. The impacts of organization and migration on males are less clear, as the separate regressions show few statistically significant results for males. To increase power and to test hypothesis concerning different coefficients across males and females, we run a pooled regression with males and females that includes gender interaction terms. In the pooled regressions, we find that being in an organized household increases schooling for both males and females. However, US migration appears to attenuate the positive effect of price premiums for males though not for females. Separating the sample by migrant and non-migrant households reveals that being organized positively affects the educational attainment of households without a migrant, but no effect is observed for youth in migrant households. A decomposition of the change in female schooling from 1995 to 2005 finds that household participation in Fair Trade-organic cooperatives contributed about a quarter of the almost two year increase in schooling between the youngest and oldest cohort, while increased US migration opportunities contributed to about two thirds of the increase.

While most of these results are consistent with the hypotheses developed above, it appears that community migration captures not only the wage effect but also the impact of remittances; hence the lack of a negative relationship between migration and schooling. Furthermore, the gender-differentiated effect of US migration on schooling suggests that migration, which is male dominated, may increase male wages relative to female wages. A closer look at the econometric estimates 
As Table 7 shows, having access to Fair Trade-organic price premiums (Organized) increases female schooling by about one year. Migration to the US (Migration US) also increases schooling for females; a one standard deviation increase in the community migration rate (13\%) is associated with about a year more of schooling. This positive effect of migration decrease as females have additional younger siblings (Migration US*Younger Siblings), suggesting that migration opportunities may burden adolescent females with additional domestic responsibilities that impede schooling.

Looking at the age fixed effects for females, we find that the 20 and 21 year olds have about 1.5 and 2.3 more years of schooling than the 22 year olds. The 21 year olds were 15 in 1999 and were the first cohort to fully participate in Oportunidades, the conditional cash program, which started late in 1998. The difference in age fixed effects is larger than Shultz's estimate that Progresa (now Oportunidades) increased years of schooling by .66. Finally, it is worth noting that many of the children in the youngest cohorts may still be in school, which would explain their smaller age fixed effects terms.

In the separate regression for males we find no statistically significant results though the coefficient on Organized is positive. Interestingly, US community migration has no effect on male schooling in contrast to the positive relationship found for females. The community migration rate probably captures the effect of migration on wages and that of remittances on community wealth; hence the lack of a negative relationship between migration and schooling. Furthermore, males migrate more than females, so to the extent that male and female workers are imperfect substitutes, migration should increase wages in male dominated activities while having less effect on female wages. A greater wage gap between males and females would favor schooling of females over males. 
The pooled model yields several noteworthy results. The coefficient on the binary indicator for gender (Female) shows that females completed about $2 / 3$ of year of school less than their male counterparts, all else constant. Consistent with the separate regression results, being part of an organized household increases schooling by about a year. The pooled model also supports (though it is not statistically significant) the hypothesis that migration opportunities reduce the impact of coffee price premiums for males (US Migration*Organized). We see a different result for females; the coefficient on (US Migration * Female * Organized) is positive, which is consistent with migration increasing male wages relative to female wages. 
Table 7: Impact of Organization, Migration and Gender on Years of School Completed

for Ages 16-25

\begin{tabular}{|c|c|c|c|c|c|c|}
\hline \multirow[b]{2}{*}{ Variable } & \multicolumn{2}{|c|}{ Males } & \multicolumn{2}{|c|}{ Females } & \multicolumn{2}{|c|}{ Pooled } \\
\hline & Coefficient & SE & Coefficient & SE & Coefficient & SE \\
\hline Organized & 0.73 & 0.65 & $1.15 \#$ & 0.61 & $0.95 *$ & 0.44 \\
\hline Female & & & & & $-0.67^{*}$ & 0.30 \\
\hline Migration US & -0.25 & 4.63 & $9.03 \#$ & 5.50 & 2.89 & 3.08 \\
\hline Migration Mex & 0.38 & 7.09 & -7.63 & 6.59 & -3.00 & 3.95 \\
\hline Older Siblings & -0.28 & 0.93 & -0.69 & 0.77 & -0.85 & 0.61 \\
\hline Younger Siblings & -0.07 & 0.95 & -0.47 & 0.71 & -0.57 & 0.62 \\
\hline Mig US*Older Siblings & 0.74 & 0.78 & -0.08 & 0.56 & 0.09 & 0.51 \\
\hline Mig US*Younger Siblings & 0.06 & 0.99 & $-1.73 \#$ & 0.84 & -0.84 & 0.57 \\
\hline Mig Mex*Older Siblings & 0.54 & 1.08 & 0.96 & 0.82 & 0.78 & 0.59 \\
\hline Mig Mex*Younger Siblings & 0.29 & 1.13 & 0.25 & 1.13 & -0.03 & 0.70 \\
\hline Migration US*Female & & & & & 2.09 & 2.24 \\
\hline Organized*Female & & & & & 0.19 & 0.48 \\
\hline Organized*Migration US & -4.36 & 3.02 & 0.06 & 3.13 & -2.68 & 2.20 \\
\hline Organized*Migration US*Female & & & & & 2.75 & 2.99 \\
\hline Age 17 & 0.00 & 0.56 & 1.05 & 0.74 & 0.38 & 0.40 \\
\hline Age 18 & 0.98 & 0.70 & $1.38^{*}$ & 0.82 & $0.83 \#$ & 0.43 \\
\hline Age 19 & -0.23 & 0.86 & 2.44 & 1.25 & 0.92 & 0.60 \\
\hline Age 20 & 0.24 & 1.01 & 1.72 & 1.06 & 0.64 & 0.61 \\
\hline Age 21 & 0.70 & 1.27 & 2.60 & 1.60 & 0.92 & 0.80 \\
\hline Age 22 & 0.97 & 1.43 & 0.32 & 1.49 & 0.16 & 0.83 \\
\hline Age 23 & 0.74 & 1.76 & 0.62 & 1.74 & 0.12 & 0.94 \\
\hline Age 24 & -0.14 & 1.75 & 0.14 & 1.77 & -0.38 & 1.00 \\
\hline Age 25 & 0.28 & 1.92 & 0.70 & 1.93 & -0.40 & 1.04 \\
\hline Intercept & 7.76 & 5.32 & 10.28 & 4.33 & 11.43 & 3.32 \\
\hline Households & 577 & 352 & 558 & 338 & 1135 & 464 \\
\hline
\end{tabular}

* significant at $5 \%$ level \# at $10 \%$ level

The final model separates the sample by whether the households had a migrant in the US in 2005. The results are consistent with our findings using the community level migration variable. For households without a migrant, joining a coffee cooperative increases their children's schooling by over a year. However, households with a US migrant do not show gains from becoming organized. This result is consistent with the results of the previous model and 
our theory. The extra income from premiums (or other income gains related to cooperative participation) has no effect on households who are likely receiving significant level of cash remittances - for the sample, the median remittance from the US is 2,000 dollars.

Table 8: Separated Estimates by Household Migration Status on Impact of Organization and Gender on Years of School Completed for Ages 16-25\#

\begin{tabular}{lcccc} 
& \multicolumn{2}{c}{ Did Not Have US Migrant 2005 } & \multicolumn{2}{c}{ Had US Migrant 2005 } \\
\hline \multicolumn{1}{c}{ Variable } & Coefficient & SE & Coefficient & SE \\
\hline Organized & $1.28^{*}$ & 0.48 & -0.14 & 0.51 \\
Female & -0.60 & 0.33 & -0.53 & 0.35 \\
Older Siblings & -0.67 & 0.82 & -0.17 & 0.66 \\
Younger Siblings & -0.21 & 0.82 & -0.68 & 0.62 \\
Organized*Female & 0.51 & 0.49 & 0.54 & 0.51 \\
$\mathrm{~N}$ Households & 622 & 263 & 513 & 201 \\
\hline
\end{tabular}

\# includes household and age fixed effects.

Decomposing Changes in Schooling (1995-2005)

The 16 year-old female cohort has an average of 1.91 more years of schooling than the 25 year old cohort. We explore how distinct trends in Southern Mexico contributed to this gain in schooling. Gains in schooling can come from changes in levels (families becoming wealthier) and from changes in coefficients (families of a given wealth having a greater propensity to invest in education). For the 16 and 25 year-old cohorts we can calculate the predicted mean level of schooling

$$
\overline{\hat{s}}^{16}=\hat{\theta} \bar{x}^{16}+\overline{\hat{\alpha}}^{16}+\hat{\gamma}^{16} \quad(9.1) ; \quad \overline{\hat{s}}^{25}=\hat{\theta} \bar{x}^{25}+\overline{\hat{\alpha}}^{25}+\hat{\gamma}^{25}
$$


where $\hat{\theta}$ is the 1 by k vector of coefficient estimates specified in the equation for the females only model, $\overline{\hat{\alpha}}^{16}$ is the mean household fixed effect for the cohort of 16 year old females and $\hat{\gamma}^{16}$ is the cohort's age fixed effect. Subtracting the predicted schooling of 16 year old females from that of 26 year old females,

$$
\bar{s}^{16}-\bar{s}^{25}=\hat{\theta}\left(\bar{x}^{16}-\bar{x}^{25}\right)+\overline{\hat{\alpha}}^{16}-\overline{\hat{\alpha}}^{25}+\hat{\gamma}^{16}-\hat{\gamma}^{25}(10)
$$

The contribution for a given covariate $\mathrm{x}_{1}$ is $\hat{\theta}\left(\bar{x}_{1}{ }^{16}-\bar{x}_{1}{ }^{25}\right)$ while the contribution for the cohort and household fixed effects are $\hat{\gamma}^{16}-\hat{\gamma}^{25}$ and $\overline{\hat{\alpha}}^{16}-\overline{\hat{\alpha}}^{25}$.

Our data do not permit us to allow all coefficients to change through time, hence changes in $\theta$ are not part of the changes in schooling between cohorts. Instead, the cohort fixed effect $\gamma$ captures the effect of being a different age in the same household while the average household fixed effect reflects differences in households with 16 year olds and households with 25 year olds.

Household participation in Fair Trade-organic cooperatives contributes .58 years of the 1.91 year increase in schooling between 16 and 25 year old females. Migration to the United States, including the interaction terms, contributes 1.3 years, more than double that of participation in cooperatives, while migration within Mexico accounts for a decrease of -.83 years, also including interactions. The contribution of age fixed effects is -.7 years. It is not surprising that the 25 year olds have a greater cohort fixed effect since 16 year olds are still in school.

The contribution of household fixed effects is 1.62 years and is large relative to the total gain in education. This contribution reflects differences between younger and older household 'cohorts', to the extent that households with 16 year olds belong to a younger household 
'cohort' than households with 25 year olds. Younger households may be more disposed to invest in education. Though they may have less wealth than older households, younger households may also invest more in education because they themselves are better educated.

Table 9: Decomposition of Educational Attainment Growth

\begin{tabular}{lc} 
Variable & Contribution \\
\hline Organized & 0.58 \\
Migration US* & 1.31 \\
Migration Mex* & -0.82 \\
Siblings* & -0.07 \\
Cohort Fixed Effect & -0.70 \\
Household Fixed Effect & 1.62 \\
\hline Total Change & 1.91 \\
\hline
\end{tabular}

*Migration US and Migration Mex also include the contribution of interaction terms involving migration.

**Siblings is the combined contribution of Younger Siblings and Older Siblings, not including interaction terms.

\section{Conclusion}

Rural communities in Southern Mexico have undergone dramatic changes on several fronts in the past two decades. In our sample of coffee producing households in Oaxaca and Chiapas, educational attainment especially for females grew rapidly between 1995 and 2005.

This article develops a formal model of education and child labor choices for a coffee producing household that yields testable hypotheses related to the effects of participation in Fair Tradeorganic cooperatives, expanding US migration opportunities, and the implementation of Progresa/Oportunidades. Several hypotheses are probed using a household fixed-effect econometric model. The estimation results are then used to develop a statistical decomposition of the factors driving educational attainment growth in the sample. 
Our results confirm the following hypotheses. First, participation in Fair Trade-organic cooperatives increases schooling more for girls than boys, and accounts in our decomposition for about 30 percent of the two-year increase in schooling of females. The stronger effect for females is consistent with greater agricultural productivity of males and/or greater opportunity costs for males in rural labor markets, and so the improvement in income associated with cooperative participation is likely to favor females. Second, access to income transfers (or higher community wages) associated with US migration significantly improved female educational outcomes, and accounted for much of the rest of their increase in schooling. These effects were more ambiguous for males, again reflecting their greater propensity to migrate and their more immediate tradeoffs than females from increased labor market opportunities. The fixed-effect regression results also support the hypothesis that conditional cash transfer programs, such as Oportunidades, increased educational attainment for females, and that this effect for females in recent years could be larger than the effect of Fair Trade-organic cooperative participation and similar to that of the migration effect. It is worth adding that the birth-order of a female shapes these impacts as well. In particular, those with younger siblings benefit less from higher US migration in their community. It seems likely that they assume responsibilities for household activities, such as child care, when a household head migrates. Overall, that is the main tradeoff we identified in terms of a factor limiting female educational attainment. Otherwise, the higher income opportunities associated with participation in Fair Trade-organic cooperatives, US migration, and Oportunidades all contributed significantly to the major gains observed in female education over the past decade.

These results may be meaningful in other contexts, especially in Central America, where participation in Fair Trade-organic coffee grew in recent years, similar US migration dynamics are underway, and conditional cash transfer programs are being piloted or implemented. Our 
results suggest that these trends can help poor families improve what have historically been dismal educational outcomes. This increased demand for education is likely to necessitate investments in the supply of education (schools and teachers) to avoid overcrowding in classrooms and shortening of school days to serve more students. In addition, because the associated migration and labor market opportunities tend to involve young males more than females, the historic pattern of greater schooling of males (by a year or so) may change and even reverse as it has in our sample in Southern Mexico. This imbalance may reflect households foregoing long-term opportunities of certain male family members to achieve broader gains for other members, and as such may warrant further attention by researchers and policymakers. 


\section{Appendix}

Changing the Timing of Organization - A Falsification Test

If participation in producer cooperatives and access to higher coffee prices causes changes in schooling, then our results should be sensitive to when a household joined a cooperative. To test if timing matters, we take all households that eventually joined cooperatives and assign them organized status before they actually become organized. If the household had one child that turned 15 before the household became organized, we assign the household organized status in that year. If the household had two or more children who turned 15 prior to becoming organized we give the household 'organized' status in the mean year when these children turned 15 (rounded up). For example, if a household become organized in 2003, and it had one child that turned 15 in 2001 and one that turned 15 in 1999 we give the household organized status in 2000. We run the pooled model as before but with the recalculated organized variable. As Table A shows, assigning households organized status before they became organized removes the effect of being organized on schooling; in the coefficient on Organized becomes negative, although not statistically significant. 
Table A: The Effect of Assigning Organized Status Prior to Becoming Organized

\begin{tabular}{|c|c|c|c|}
\hline Variable & Coefficient & SE & P Value \\
\hline Fake Organized & -0.52 & 0.39 & 0.179 \\
\hline Female & -0.64 & 0.33 & 0.054 \\
\hline Migration US & -0.25 & 1.87 & 0.892 \\
\hline Migration Mex & -0.64 & 2.42 & 0.793 \\
\hline Migration US*Female & 4.84 & 2.06 & 0.019 \\
\hline Fake Organized*Female & 0.09 & 0.45 & 0.842 \\
\hline Fake Organzied*Migration US & 2.61 & 2.55 & 0.307 \\
\hline Fake Organized*Migration US*Female & -3.66 & 3.35 & 0.275 \\
\hline Age 17 & 0.32 & 0.40 & 0.432 \\
\hline Age 18 & 0.79 & 0.41 & 0.054 \\
\hline Age 19 & 0.82 & 0.51 & 0.105 \\
\hline Age 20 & 0.49 & 0.49 & 0.319 \\
\hline Age 21 & 0.72 & 0.63 & 0.254 \\
\hline Age 22 & 0.03 & 0.65 & 0.959 \\
\hline Age 23 & 0.00 & 0.72 & 1 \\
\hline Age 24 & -0.41 & 0.74 & 0.576 \\
\hline Age 25 & -0.46 & 0.77 & 0.548 \\
\hline Intercept & 8.42 & 1.10 & 0 \\
\hline Households & 464 & $\mathrm{~N}$ & 1135 \\
\hline
\end{tabular}




\section{Works Cited}

Amuedo-Dorantes, C. and S. Pozo, 2006, Migration, remittances, and male and female employment patterns. American Economic Review 96(2): 222-226.

Basu, K., 1999, Child labor: Cause, consequence and cure, with remarks on international labor standards, Journal of Economic Literature 37: 1086-1113.

Becker, G.S., 1964, Human Capital: a theoretical and empirical analysis, with special reference to education, Columbia University Press: New York; 1964.

Beegle, K., R. Dehejia and R. Gatti, 2003. "Child Labor, Crop Shocks, and Credit Constraints," NBER Working Papers 10088, National Bureau of Economic Research, Inc

Borjas, G, 1987, Self-selection and the earnings of immigrants, American Economic Review 77(4): 531-553.

Brown, P. and A. Park, 2002, "Education and Poverty in Rural China" Economics of Education Review, 21, 6: 523-41

Chiquiar, D. and G. Hanson, 2005, International migration, self-selection, and the distribution of wages: Evidence from Mexico and the United States, Journal of Political Economy 113 (2): 239-81.

Clark, X., T. Hatton and J. Williamson, 2004, What explains emigration out of Latin America? World Development 32 (11): 1871-1890.

Davis, B., G. Stecklov and P. Winters, 2002, Domestic and International Migration from Rural Mexico: Disaggregating the effects of network structure and composition, Population Studies 56 (3): 291-309.

Janvry, A. de, F. Finan, E. Sadoulet and R. Vakis, 2006, Can conditionnal cash transfers serve as safety nets in keeping children at school and from working when exposed to shocks? Journal of Development Economics 79(2): 349-373.

Edwards, A.C. and M. Ureta, 2003, International migration, remittances, and schooling: Evidence from El Salvador, Journal of Development Economics 72 (2): 429-461.

Feder, G., 1980, Farm size, risk aversion, and the adoption of new technology under uncertainty, Oxford Economic Papers 32(2): 263-283.

Fiszbein, A. and N. Schady, 2009, Conditional cash transfers: Reducing present and future poverty, World Bank, Washington DC.

FLO, 2009, Generic Fair Trade standards for small producers' organizations, http://www.Fair Trade.net/fileadmin/user upload/content/Jan 2009 EN Generic Fair Trade Standards SPO.pdf

Giovannucci, D., P. Liu and A. Byers, 2008, In: Pascal Liu, Editor, Value-added standards in the North American market - Trade opportunities for certified products for developing 
countries. FAO Commodities and Trade Technical Paper 11.

Gitter, S.R. and B. Barham, 2009, Conditional cash transfers, shocks, and school enrollment in Nicaragua, Journal of Development Studies 45(10): 1-21.

Gitter, S.R. and B. Barham, 2007, Education in rural Honduras: The effects of credit access, crop choice, and natural disasters on secondary school attainment, World Development 35(3), 498-511.

Hanushek, E., 1986, The economics of schooling: Production and efficiency in public schools, Journal of Economic Literature 24(3): 1141-1177.

Hoddinott, J. and D. Wiesmann, 2008, The impact of conditional cash transfer programs on food consumption in Honduras, Mexico, and Nicaragua, Available at SSRN: http://ssrn.com/abstract=1269417

Kruegar, D., 2007, Coffee production effects on child labor and schooling in rural Brazil, Journal of Development Economics 82 (2): 448-463.

Levison,D. , K. Moe and F. Knaul, 2001, Youth education and work in Mexico, World Development 29 (1), 167-188.

Lewis, J. and D. Runsten, 2009, Coffee, Migration, and Environment in Southern Mexico: A Study of 15 Communities in Oaxaca and Chiapas. A report to the Rockefeller Foundation.

Massey,D., L. Goldring and J. Durand, 1994, Continuities in transnational migration: an analysis of nineteen Mexican communities, American Journal of Sociology 99 (6), 1492-1533.

Mckenzie, D. and H. Rapoport, 2007a, Migration and education inequality in rural Mexico, Integration and Trade Journal July-December: 135-158.

Mckenzie, D. and H. Rapoport, 2007b, Network effects and the dynamics of migration and inequality: Theory and evidence from Mexico, Journal of Development Economics 84(1): $1-24$.

Mehta, A. and H. Villarreal, 2008, Why do diplomas pay? An expanded Mincerian framework applied to Mexico, Applied Economics 40(24): 3127-3144.

Migration and Policy Institute. Country and Comparative Data: United States. Accessed in October, 2009.

http://www.migrationinformation.org/DataHub/countrydata/country.cfm.

Rawlings, L. and G. Rubio, 2005, Evaluating the impact of conditional cash transfer programs, World Bank Research Observer 20: 29-55. 
Schultz, P.T. 2004, School subsidies for the poor: evaluating the Mexican Progresa poverty program, Journal of Development Economics 74(1): 199-250.

Varangis, P. Siegel, D. Giovanucci and B. Lewin, 2003, Dealing with the Central America region coffee crisis: Impacts and strategies. Policy Research Working Paper 2993. 